Acta vet. scand. $1976,17,15-24$.

From the State Veterinary Serum Laboratory, Department for Jutland, Århus, Denmark.

\title{
STUDIES ON THE OCCURRENCE OF PEPTOCOCCUS INDOLICUS AND CORYNEBACTERIUM PYOGENES IN APPARENTLY HEALTHY CATTLE
}

By

Gunner Høi Sørensen

HØI SØRENSEN, GUNNER: Studies on the occurrence of Peptococcus indolicus and Corynebacterium pyogenes in apparently healthy cattle. Acta vet. scand. 1976,17, 15-24. - A total of 1050 samples from apparently healthy cattle were examined bacteriologically with special regard to Pc. indolicus and $\mathrm{Cb}$. pyogenes.

Pc. indolicus was found in $58 \%$ of 130 samples from tonsils (slaughterhouse material), in $23 \%$ of 620 samples from the vagina of cows, in $22 \%$ of 100 samples from the vagina of calves and heifers, in $5 \%$ of 100 samples from the conjunctival sac of cows, and in $10 \%$ of 1.00 samples from the nasal cavity of cows (Table 1). Cb. pyogenes was found in $51 \%, 17 \%, 19 \%, 8 \%$, and $6 \%$, respectively. Both organisms were found in each of 9 herds examined, though with varying frequency (Tables 2,3 , and 4 ).

Altogether Pc. indolicus was found in $254(24 \%)$ and $\mathrm{Cb}$. pyogenes in $205(20 \%)$ of the samples examined (Table 1 ). In 127 samples both organisms were present. Eleven of the strains of Pc. indolicus were $\beta$-hemolytic, the rest non-hemolytic.

By gel diffusion analysis the strains of Pc. indolicus as well as those of $\mathrm{Cb}$. pyogenes could be identified with strains originating from pathological conditions in cattle. With Serotype B occurring most frequently, usually two or three different types of Pc. indolicus were found in each of the herds examined (Tables 5, 6, and 7).

The investigation has shown that Pc. indolicus is widespread among healthy cattle, and given evidence to suggest that Pc. indolicus and $\mathrm{Cb}$. pyogenes are natural cohabitants.

Peptococcus indolicus; Corynebacterium pyogenes; healthy cattle; vagina; tonsils; conjunctiva; nas a l cavity.

Peptococcus indolicus was first described by Christiansen in 1934 under the name Micrococcus indolicus. In accordance with present-day nomenclature the name Peptococcus indolicus has been suggested by $H \phi i$ S $\phi r e n s e n$ (1974 a). Antigenically as well 
as biochemically Pc. indolicus has been found to be a well defined species, divisible in a number of precipitin-types (H $\phi i$ S $\phi$ rensen 1973). It has mainly been demonstrated in summer mastitis secretions, typically occurring together with Corynebacterium pyogenes and/or other bacteria (Leth Jørgensen 1937, 1966,

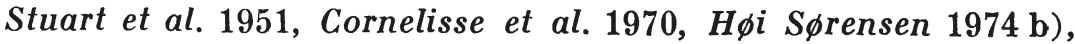
but it has been isolated from other conditions in cattle as well

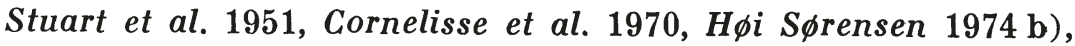
found in the interdigital skin and in the vagina of a few apparently healthy cows (H $\phi i$ S $\phi$ rensen 1973). More detailed information about its spread among healthy cattle does not seem to be available.

Cb. pyogenes is considered to be responsible for a variety of suppurative processes in cattle, and such "pyogenes-infections" may cause great economic losses. As is well known, however, $\mathrm{Cb}$. pyogenes often occurs together with other organisms, and in summer mastitis it has been shown experimentally that Pc. indolicus as well as $\mathrm{Cb}$. pyogenes is of etiological significance (Stuart et al., Hфi Sфrensen 1972).

Reports on the occurrence of $\mathrm{Cb}$. pyogenes in healthy cattle are numerous; for example it has been demonstrated in the vagina by Francis (1941), in tonsils by Francis and Grupe (1963), and in the conjunctival sac and the nasal cavity by Skovgaard (1968).

The present investigation was carried out in order to elucidate the spread of Pc. indolicus among healthy cattle, with special reference to its possible occurrence together with $\mathrm{Cb}$. pyogenes. Samples were therefore collected from sources known often to harbour this latter organism.

\section{MATERIAL AND METHODS}

A total of 1050 samples from clinically healthy cattle were examined. The samples were taken with sterile cotton swabs from the following sites:

The vagina. Six hundred and twenty samples were taken from cows in 9 herds, mainly of SDM breed (3 samplings at monthly intervals) and 100 from calves and heifers, aged 2 to 18 months, in 5 of these 9 herds ( 1 sampling). The samples were taken $5-10 \mathrm{~cm}$ inside the vagina.

The conjunctival sac and the nasal cavity. One sample from 
each of these sites were taken from 100 cows in 4 of the abovementioned 9 herds. Samples were taken from both sites in one operation.

Tonsils (slaughter-house material). One hundred samples were taken from tonsils of cows (pooled material from the two tonsils of each cow), and 30 from tonsils of 15 young bulls of ab. $300 \mathrm{~kg}$ body weight (1 sample from each tonsil). The tonsils were transported to the laboratory in sterile plastic bags. After opening of the tonsillar sinus and removal of the mucous content with a glowing steel spatula, the content of a crypt was pressed out and collected with a swab.

Cultures on blood-agar plates were made from the samples within a few hours after they had been collected. The plates were incubated anaerobically at $37^{\circ} \mathrm{C}$ for $48-72 \mathrm{hrs}$. in "B T L ANAEROBIC JARS" with hydrogen and $10 \%$ carbon dioxide added.

Pc. indolicus was identified on biochemical and serological criteria (gel diffusion analysis) as described by Hфi Sфrensen (1973), Cb. pyogenes by gel diffusion analysis (Hфi Sфrensen $1974 \mathrm{c})$.

\section{RESULTS}

Pc. indolicus was isolated from 254 and $\mathrm{Cb}$. pyogenes from 205 of the 1050 samples examined. In 127 samples both organisms were present, and both were demonstrated in all of the 9 herds and in all of the 4 sites comprised by the study (Table 1). Eleven

Table 1. Bacteriological examination of samples from the vagina, the conjunctival sac, the nasal cavity, and tonsils of apparently healthy cattle. (The total material studied).

\begin{tabular}{|c|c|c|c|c|c|c|}
\hline \multirow[b]{3}{*}{ Sites examined } & \multirow{3}{*}{$\begin{array}{l}\text { Number } \\
\text { of samples }\end{array}$} & \multicolumn{3}{|c|}{ Positive } & \multicolumn{2}{|c|}{$\%$ positive } \\
\hline & & \multicolumn{2}{|c|}{ total } & \multirow{2}{*}{$\begin{array}{l}\text { Pc. ind.+Cb. pyog. } \\
\text { (in same sample) }\end{array}$} & \multirow[b]{2}{*}{ Pc. ind. } & \multirow[b]{2}{*}{ Cb.pyog. } \\
\hline & & Pc.ind. & Cb.pyog. & & & \\
\hline Vagina, cows & 620 & 142 & 106 & 71 & 23 & 17 \\
\hline Vagina, calves and heifers & 100 & 22 & 19 & 11 & 22 & 19 \\
\hline Conjunctival sac, cows & 100 & 5 & 8 & 2 & 5 & 8 \\
\hline Nasal cavity, cows & 100 & 10 & 6 & 0 & 10 & 6 \\
\hline Tonsils, cows and young bulls & 130 & 75 & 66 & 43 & 58 & 51 \\
\hline Total & 1050 & 254 & 205 & 127 & 24 & 20 \\
\hline
\end{tabular}

* Of 15 sets of tonsils from young bulls, 11 (73\%) gave growth of Pc. indolicus and $13(87 \%)$ of $\mathrm{Cb}$. pyogenes. 
strains of Pc. indolicus (9 of vaginal origin, all from cows in Herd VIII, and 2 originating from tonsils of cows) were $\beta$-hemolytic, whereas the rest of the Pc. indolicus strains were nonhemolytic.

The positive findings are listed in Tables 1 (the total material studied), 2 and 3 (samples from, respectively, the vagina of cows and the vagina of calves and heifers), and 4 (samples from the conjunctival sac and the nasal cavity of cows).

Table 2. The occurrence of Peptococcus indolicus and Corynebacterium pyogenes in the vagina of apparently healthy cows in 9 herds. (Three samplings at approximately monthly intervals. Cows not represented at all samplings not included).

\begin{tabular}{|c|c|c|c|c|c|}
\hline \multirow[b]{3}{*}{ Herd } & \multirow{3}{*}{$\begin{array}{l}\text { Number } \\
\text { of cows }\end{array}$} & \multicolumn{4}{|c|}{ Positive at 1,2 , or 3 samplings } \\
\hline & & \multicolumn{2}{|c|}{ total } & \multicolumn{2}{|c|}{$\%$} \\
\hline & & Pc. ind. & Cb. pyog. & Pc. ind. & Cb. pyog. \\
\hline $\mathbf{I}$ & 22 & 12 & 9 & 55 & 41 \\
\hline II & 18 & 5 & 3 & 28 & 17 \\
\hline III & 10 & 2 & 1 & 20 & 10 \\
\hline IV & 19 & 11 & 9 & 58 & 47 \\
\hline V & 36 & 16 & 10 & 44 & 28 \\
\hline VI & 24 & 17 & 14 & 71 & 58 \\
\hline VII & 19 & 8 & 13 & 42 & 68 \\
\hline VIII & 13 & 10 & 8 & 77 & 62 \\
\hline IX & 31 & 15 & 14 & 48 & 45 \\
\hline Total & 192 & 96 & 81 & 50 & 42 \\
\hline
\end{tabular}

Table 3. The occurrence of Peptococcus indolicus and Corynebacterium pyogenes in the vagina of apparently healthy calves and heifers. (One sampling).

\begin{tabular}{lcccc}
\hline & & \multicolumn{3}{c}{ Positive } \\
\cline { 3 - 5 } Herd & $\begin{array}{c}\text { Number } \\
\text { of animals }\end{array}$ & \multicolumn{2}{c}{ total } & Pc. ind. + Cb. pyog. \\
\cline { 3 - 5 } (in same sample) & Pc. ind. & Cb. pyog. & (in \\
\hline I & 30 & 4 & 2 & 1 \\
II & 9 & 0 & 0 & 0 \\
III & 8 & 0 & 0 & 0 \\
IV & 21 & 9 & 11 & 7 \\
V & 32 & 9 & 6 & 3 \\
\hline Total & 100 & 22 & 19 & 11 \\
\hline
\end{tabular}


All of the 254 strains of Pc. indolicus fulfilled the biochemical eriteria of this species, and by gel diffusion analysis they could all be referred to one of the serotypes A, B, C, D, or E, whereas none of them were of Type $F$ (Table 5 ). The type distribution appeared to be independent of the origin of the strains (Table 5) and in 8 of the 9 herds examined 2 or 3 different types were found (Tables 6 and 7). In 1 herd (Herd III) only 1 type (Type C) was demonstrated. In 30 cows Pc. indolicus was demonstrated in more than 1 of the samples collected from the vagina. In 24 of these cases the 2 or 3 strains isolated agreed antigenically, while they differed in 6 cases. In 8 cows Pc. indolicus was isolated from the conjunctival sac and/or from the nasal cavity

T a ble 4. The occurrence of Peptococcus indolicus and Corynebacterium pyogenes in the conjunctival sac and the nasal cavity of apparently healthy cows in 4 herds. (One sample from the conjunctival sac (left or right) and one from the nasal cavity (left or right) from each animal).

\begin{tabular}{|c|c|c|c|c|c|}
\hline \multirow[b]{3}{*}{ Herd } & \multirow{3}{*}{$\begin{array}{l}\text { Number } \\
\text { of cows }\end{array}$} & \multicolumn{4}{|c|}{ Positive } \\
\hline & & \multicolumn{2}{|c|}{ Conjunct. sac } & \multicolumn{2}{|c|}{ Nasal cavity } \\
\hline & & Pc. ind. & $\mathrm{Cb}$. pyog. & Pc. ind. & Cb. pyog. \\
\hline I & 26 & 0 & 0 & 0 & 0 \\
\hline VI & 26 & 1 & 5 & 1 & 3 \\
\hline VIII & 15 & 0 & 0 & 1 & 1 \\
\hline IX & 33 & 4 & 3 & 8 & 2 \\
\hline Total & 100 & 5 & 8 & 10 & 6 \\
\hline
\end{tabular}

Table 5. Serotyping of Peptococcus indolicus. (The type distribution in the total material studied).

\begin{tabular}{|c|c|c|c|c|c|c|c|}
\hline \multirow[b]{2}{*}{ Origin of strains } & \multirow{2}{*}{$\begin{array}{l}\text { Number } \\
\text { of strains }\end{array}$} & \multicolumn{6}{|c|}{ Serotype } \\
\hline & & $\mathbf{A}$ & B & C & $\mathbf{D}$ & $\mathbf{E}$ & $\mathbf{F}$ \\
\hline Vagina, cows & 142 & 0 & 56 & 27 & 24 & 35 & 0 \\
\hline Vagina, calves and heifers & 22 & 0 & 8 & 1 & 4 & 9 & 0 \\
\hline Conjunctival sac, cows & 5 & 0 & 2 & 2 & 1 & 0 & 0 \\
\hline Nasal cavity, cows & 10 & 0 & 6 & 2 & 0 & 2 & 0 \\
\hline Tonsils, cows and young bulls & 75 & 2 & 29 & 15 & 13 & 16 & 0 \\
\hline Total & 254 & 2 & .101 & 47 & 42 & 62 & 0 \\
\hline
\end{tabular}


besides from the vagina. In 5 of these cases the strains from different sites were of the same serotype, while they were of different types in 3 cases. In 2 cows Pc. indolicus was found both in the conjunctival sac and in the nasal cavity; in both cases the strains from the 2 sites were of different serotypes.

By gel diffusion analysis all of the 205 strains of $\mathrm{Cb}$. pyogenes were found to agree antigenically with Strain S-2, originating from a summer mastitis secretion.

T a b l e 6. Serotyping of Peptococcus indolicus. The type distribution of strains originating from the vagina of apparently healthy cows in 9 herds.

\begin{tabular}{lrrrr}
\hline & \multicolumn{5}{c}{ Number of strains classified as Type } \\
\cline { 2 - 5 } Herd & B & C & D & E \\
\hline I & 6 & 0 & 7 & 4 \\
II & 1 & 3 & 0 & 1 \\
III & 0 & 4 & 0 & 0 \\
IV & 0 & 4 & 4 & 7 \\
V & 22 & 0 & 0 & 3 \\
VI & 13 & 0 & 10 & 1 \\
VII & 6 & 0 & 3 & 4 \\
VIII & 2 & 10 & 0 & 0 \\
IX & 6 & 6 & 0 & 15 \\
\hline Total & 56 & 27 & 24 & 35 \\
\hline
\end{tabular}

* Of $9 \beta$-hemolytic strains 1 was of Serotype B and 8 of Type C.

T a b le 7. Serotyping of Peptococcus indolicus. The type distribution of strains originating from the conjunctival sac and the nasal cavity of cows in herds VI, VIII, and IX.

\begin{tabular}{|c|c|c|c|c|c|}
\hline \multirow[b]{2}{*}{ Herd } & \multirow[b]{2}{*}{ Origin } & \multicolumn{4}{|c|}{ Number of strains classified as Type } \\
\hline & & B & C & D & $\mathbf{E}$ \\
\hline VI & $\begin{array}{l}\text { Conjunctival sac } \\
\text { Nasal cavity }\end{array}$ & $\begin{array}{l}1 \\
1\end{array}$ & & & \\
\hline VIII & Nasal cavity & 1 & & & \\
\hline IX & $\begin{array}{l}\text { Con:unctival sac } \\
\text { Nasal cavity }\end{array}$ & $\begin{array}{l}1 \\
4\end{array}$ & $\begin{array}{l}2 \\
2\end{array}$ & & $\begin{array}{l}1 \\
2\end{array}$ \\
\hline Total & & 8 & 4 & 0 & 3 \\
\hline
\end{tabular}




\section{DISCUSSION}

The results of this investigation show that Pc. indolicus is widespread among healthy cattle, and that it often occurs together with $\mathrm{Cb}$. pyogenes (Table 1 ). The fact that the distribution of the 2 organisms is similar in all the sites examined may even suggest that they are natural cohabitants. This is of initerest, since in summer mastitis secretions they are typically found together (Leth Jørgensen 1937, 1966, Stuart et al. 1951, Cornelisse et al. 1970, Høi Sørensen 1974 b) and because it has been demonstrated experimentally that both of them are of etiological

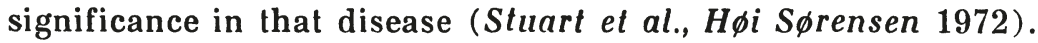

Pc. indolicus and $\mathrm{Cb}$. pyogenes were found remarkably frequent in tonsils (Table 1), and although they often dominated the flora on primary plates, they may well have been overlooked on plates with dense growth of other organisms. The actual carrier rate is therefore probably even higher than the recorded findings would indicate.

The 2 organisms were also found very frequently in the vagina, both in cows and in calves and heifers (Tables 1,2 , and 3 ), but the incidence of positive findings in the vagina varied from herd to herd.

Pc. indolicus and $\mathrm{Cb}$. pyogenes were demonstrated also in samples from the conjunctival sac and the nasal cavity, though at a low frequency compared with the rest of the material studied (Tables 1 and 4).

In a previous report (Høi Sфrensen 1975) the 9 strains of the $\beta$-hemolytic variety of Pc. indolicus, which were all of vaginal origin, were described together with an $\alpha$-hemolytic porcine variety. These $9 \beta$-hemolytic strains originated from 8 cows, which, interestingly enough, all belonged to 1 herd (Herd III). Until now, $\alpha$-hemolytic strains have not been found in cattle.

Altogether 254 strains of Pc. indolicus were isolated from apparently healthy cattle, and all of them were found to agree biochemically as well as serologically with strains from pathological material (cf. Høi Sфrensen 1973). However, it should be noted that while Type $\mathrm{C}$ was the commonest type among strains from pathological material, Type B was predominant among strains from healthy cattle (Table 5).

Considering the high carrier rate it is not surprising that 2 or 3 precipitin types of Pc. indolicus were usually found in each herd (Tables 6 and 7). Nor is it surprising that different 
types could be demonstrated on different mucous membranes of the same animal, or, occasionally, even on the same mucous membrane.

Till now, Type $F$ has not been isolated from cattle.

By gel diffusion analysis (cf. Kielstein \& Kötsche 1963, 1966, and $H \phi i$ S $\phi$ rensen 1974c) the strains of Cb. pyogenes originating from healthy cattle were found to agree antigenically with strains originating from pathological material.

\section{CONCLUSION}

Pc. indolicus is widespread among apparently healthy cattle. It is often found together with $\mathrm{Cb}$. pyogenes, and there is some evidence of the 2 organisms being natural cohabitants.

The hemolytic varieties of Pc. indolicus seem to be of limited distribution.

Of the 6 precipitin types of Pc. indolicus Type B seems to be most commonly occurring in healthy cattle.

The tonsils serve as an essential habitat for Pc. indolicus and Cb. pyogenes, but both organisms are commonly occurring also in the vagina, and can be demonstrated in the conjunctival sac and in the nasal cavity as well.

Strains of $\mathrm{Pc}$.indolicus and $\mathrm{Cb}$.pyogenes originating from healthy cattle have been found to be identical with strains originating from pathological conditions in cattle.

\section{REFERENCES}

Christiansen, M.: Ein obligat anaerober, gasbildender, indolpositiver Mikrokokkus (Micrococcus indolicus N.Sp.). (An anaerobic, gas-producing, indole-positive Micrococcus). Acta path. microbiol. scand. 1934, Suppl. XVIII, 42-63.

Cornelisse, J. L., J. M. F. Saes \& J. C. Atteveld: De isolatie van anaerobe streptokokken, peptostreptokokken, uit uirsecretum van rundern met wrang. (Isolation of anaerobic streptococci (peptostreptococci) from mammary secretions of cows with summermastitis). T. Diergeneesk. 1970, 95, 387-391.

Francis, J. A.: A bacteriological examination of bovine tonsils and vaginas. Vet. J. $1941,97,243-251$.

Grupe, W.: Untersuchungen von Rindertonsillen auf das Vorkommen von C. pyogenes. (A study of bovine tonsils for the occurrence of C. pyogenes). Thesis. Berlin 1963.

Høi Sørensen, G.: Sommermastitis - eksperimentelt fremkaldt hos juvenile kvier. (Summermastitis, experimentally produced in juvenile heifers). Nord. Vet.-Med. 1972, 24, 247-258. 
Høi Sфrensen, G.: Micrococcus indolicus. Some biochemical properties, and the demonstration of six antigenically different types. Acta vet. scand. 1973, 14, 301-326.

Høi Sørensen, G.: Peptococcus indolicus. Its occurrence, identification, and classification. XI Conf. Taxonomy Bacteria, Brno 1974 a.

Høi Sфrensen, G.: Studies on the aetiology and transmission of summermastitis. Nord. Vet.-Med. 1974 b, 26, $122-132$.

Høi Sørensen, G.: Corynebacterium pyogenes. A biochemical and serological study. Acta vet. scand. 1974 c, 15, 544-554.

Høi Sørensen, G.: Peptococcus (s. Micrococcus) indolicus. The demonstration of two varieties of hemolysin forming strains. Acta vet. scand. $1975,16,218-225$.

Kielstein, P. \& W. Kötsche: Zur Differenzierung der aus tierischen Untersuchungsmaterial stammenden Corynebacterien. (Differentiation of corynebacteria isolated from animals). Arch. exp. Vet.-Med. 1963, 17, 449-460.

Kielstein, P. \& W. Kötsche: Untersuchungen zur biochemischen und serologischen Abgrenzung von Corynebacterien tierischer und menschlischer Herkunft. (Investigations on the biochemical and serological differences between corynebacteria of animal and human origin). Mh. Vet.-Med. 1966, 21, 20-26.

Leth Jørgensen, K.: Mastitis fremkaldt af en Blandingsinfektion med Bact. pyogenes og anaerobe Mikrokokker. (Mastitis caused by mixed infection with $\mathrm{Cb}$. pyogenes and anaerobe micrococci). Maanedsskr. f. Dyrl. 1937, 49, 113-129.

Leth Jørgensen, K.: Sommermastitis, årsagsforhold og udbredelse. (Summermastitis: aetiology and prevalence). Medlemsbl. danske Dyrlægeforen. 1966, 49, 277-287.

Skovgaard, N.: The incidence of hemolytic bacteria in cattle with a special view to Corynebacterium pyogenes as the causative agent of "summer-mastitis". Den kgl. Veterinær- og Landbohøjskoles Årsskrift 1968, 89-108.

Stuart, P., D. Buntain \& R. G. Langridge: Bacteriological examination of udder secretions from cases of "summer mastitis" and experimental infection of non-lactating bovine udders. Vet. Rec. 1951, $63,451-453$.

\section{SAMMENDRAG}

Unders $\phi$ gelser over forekomsten af Peptococcus indolicus og Corynebacterium pyogenes hos tilsyneladende sundt kvæg.

Unders $\varnothing$ gelsen omfatter 1050 svaberpr $\varnothing v e r$ fra tilsyneladende sundt kvæg. Sekshundredeogtyve prøver var fra vagina af køer i 9 besætninger, 100 fra vagina af kalve og kvier i 5 af de 9 besætninger, 100 fra konjunktivalsæk og 100 fra næseslimhinde af køer i 4 af de 9 besætninger, og 130 var fra tonsiller fra køer og ungtyre (slagtehusmateriale).

Pc. indolicus blev isoleret fra ialt $254(24 \%)$ og $\mathrm{Cb}$. pyogenes fra ialt $205(20 \%)$ af de unders $\varnothing$ gte pr $\varnothing$ ver (tabel 1). I 127 pr $\varnothing$ ver blev 
begge bakteriearter påvist. Elleve af de isolerede Pc. indolicus stammer var $\beta$-hæmolytiske, de $\phi$ vrige non-hæmolytiske.

Pc. indolicus blev påvist i $58 \%$ af tonsilpodningerne, i $23 \%$ af vaginalpodningerne fra køer, i $22 \%$ af vaginalpodningerne fra kalve og kvier, i $5 \%$ af konjunktivalpodningerne og i $10 \%$ af næsepodningerne (tabel 1). Cb. pyogenes blev i de tilsvarende prøver påvist i henholdsvis $51 \%, 17 \%, 19 \%, 8 \%$ og $6 \%$. Begge bakteriearter blev påvist $i$ alle de unders $\varnothing$ gte besætninger, omend med varierende hyppighed (tabel 2, 3 og 4).

Såvel Pc. indolicus stammerne som $\mathrm{Cb}$. pyogenes stammerne fandtes identiske med stammer isoleret fra patologisk materiale fra kvæg (gel diffusions analyse). Oftest påvistes 2 eller 3 forskellige serotyper af Pc. indolicus $i$ hver af de unders $\varnothing$ gte besætninger (tabel 6 og 7), og type B var den hyppigst isolerede i det samlede materiale (tabel 5).

Resultaterne viser, at Pc. indolicus er almindeligt forekommende hos sundt kvæg, og de tyder endvidere på, at Pc. indolicus og $\mathrm{Cb}$. pyogenes typisk forekommer sammen.

(Received November 17, 1975).

Reprints may be requested from: Gunner Høi Sørensen, the State Veterinary Serum Laboratory, Hang $\varnothing$ vej 2, DK-8200 Århus N, Denmark. 